\title{
Micro-shear Bond Strength of Aged Resin Composite Repaired with Different Universal Adhesives
}

\author{
Farklı Üniversal Adezivlerle Tamir Edilen Yaşlandırılmış Kompozit \\ Rezinin Mikro-Makaslama Bağlanma Dayanımı \\ (D) Gülbike Demirel, (D) Gürkan Gür
}

Ankara University Faculty of Dentistry, Department of Restorative Dentistry, Ankara, Turkey

Keywords

Universal adhesives, composite repair, microshear bond strength

Anahtar Kelimeler

Üniversal adeziv, kompozit tamiri, mikromakaslama bağlanma dayanımı

Received/Geliş Tarihi : 09.01.2018

Accepted/Kabul Tarihi : 03.08.2018

doi:10.4274/meandros.galenos.2018.43760

Address for Correspondence/Yazışma Adresi: Gülbike Demirel DDS, PhD,

Ankara University Faculty of Dentistry, Department of Restorative Dentistry, Ankara, Turkey

Phone : +90 3122965594

E-mail : gulbikedemirel@gmail.com

ORCID ID: orcid.org/ 0000-0002-0828-0532

(C) Meandros Medical and Dental Journal, Published by Galenos Publishing House.

This is article distributed under the terms of the Creative Commons Attribution NonCommercial 4.0 International Licence (CC BY-NC 4.0).

\begin{abstract}
Objective: This study evaluated the effect of two different universal adhesives on the repair bond strength of aged resin composite.

Materials and Methods: Forty-four composite resin disks were prepared (5 mm x $3 \mathrm{~mm}$ ). The composite disks randomly assigned into four groups after aging. Specimens were repaired with resin composite using four different repair procedure; Porcelain primer + Clearfil S3 Bond Plus, Single Bond Universal, Clearfil Universal Bond, Clearfil S3 Bond Plus, then they were subjected to micro-shear bond strength testing. Data were analyzed using ANOVA and Tukey's HSD $(p<0.05)$.

Results: Additional silane treatment significantly affected the repair bond strengths $(p<0.05)$. No statistical difference was found in repaired groups with universal adhesives. One-step self-etch adhesive showed lower bond repair strength values in aged composite repair $(\mathrm{p}<0.05)$.

Conclusion: Repair of composite restorations with universal adhesives cannot suggest without additional silane application.
\end{abstract}

Öz

Amaç: Bu çalışma iki farklı üniversal adeziv sistemin yaşlandırılmış rezin kompozitlerin tamir bağlanma dayanımı üzerindeki etkileri incelemektedir.

Gereç ve Yöntemler: Kırk dört adet kompozit disk hazırlanmıştır (5 mm x $3 \mathrm{~mm}$ ). Kompozit disklerin yaşlandırılmasının ardından (ısıl-döngü 10.000), rastgele dört gruba ayrılmıştır. Örnekler rezin kompozit ile dört farklı tamir prosedürü izlenerek tamir edilmiştir: Porselen primer + Clearfil S3 Bond Plus, Single Bond Universal, Clearfil Universal Bond, Clearfil S3 Bond Plus, ardından mikro-makaslama bağlanma dayanımı testi uygulanmıştır. Veriler ANOVA ve Tukey's HSD kullanılarak analiz edilmişlerdir $(p<0,05)$.

Bulgular: İlave silan uygulanması tamir bağlanma dayanımını önemli ölçüde etkilemiştir $(p<0,05)$. Üniversal adezivler ile tamir edilen gruplar arasında istatistiksel olarak anlamı bir fark yoktur. Tek-basamaklı kendinden asitli adeziv diğer gruplardan daha düşük tamir dayanımı göstermiştir.

Sonuç: Üniversal adezivlerin, ilave silan uygulaması olmaksızın tek başına kompozit rezinlerin tamirinde kullanılması önerilmez. 


\section{Introduction}

Following the improvements in the bonding systems, curing systems and enhanced mechanical and physical properties of the resin systems, composite resin restorations have become routine in restorative dentistry. However, similar to other restorative materials, composite resin restorations have limited longevity (1). Failed restorations are generally totally replaced and results in considerable amount of tooth structure loss (2). Consistent with "minimum intervention" dentistry philosophy, it is suggested that the defective restorations should first be evaluated for the repair options rather than total replacement (3).

In general, bonding between two composite layers is achieved in the presence of an oxygen inhibited layer of unpolymerized resin (4). Aged composite restorations do not contain unpolymerized surface layer. In order to successfully repair such aged composite restorations, a strong bond should be create between the old composite restoration and the new repair material.

Mechanical retention can be created with several methods. These methods include creating retention holes and undercuts, roughening the surface with diamond burs, applying phosphoric or hydrofluoric acid to the surface and applying air abrasion with silica coated alumina particles.

In addition, chemical bond between aged composite and repair material may be achieved by applying special primers as silane coupling agents (58).

Currently repair systems with various conditioning protocols and adhesive systems are commercially available. "Universal adhesives" are simplified systems, usually containing all bonding components in a single bottle (9-11). They can be applied either in etch-andrinse or self-etching bonding protocols according to manufacturer's instructions. Some universal adhesives may contain silane in their composition and eliminates the silanization step when bonding to glass ceramics, hybrid materials and resin composites.

The studies investigating the (12-14) different repair systems and protocols are available; however, there is lack of information regarding the use of universal adhesives to repair the aged composite restorations. Therefore, the aim of this study is to investigate the micro-shear bond strength ( $\mu \mathrm{SBS}$ ) of different universal adhesive systems applied on aged composite resins.

\section{Materials and Methods}

\section{Specimen Preparation}

Forty-four resin composite disc shape sample (5 $\mathrm{mm}$ diameter, $3 \mathrm{~mm}$ height) were prepared in a custom-made stainless steel mold with a resin composite (Clearfil Majesty Esthetic, Kuraray, Osaka, Japan). Each increment was cured for $20 \mathrm{~s}$ with a light emitting diode curing unit (SDI Radii Plus, SDI Limited, Australia). Light intensity was assured to be higher than $1000 \mathrm{~mW} / \mathrm{cm}^{2}$ (Hilux Ledmax curing lightmeter Benlioglu Dental, Turkey).

To create a uniform surface, top surfaces of the samples were abraded with 600 grit silicon carbide papers (P1000-P4000Metkon, Gripo 2v GrinderPolisher, Turkey). All discs were cleaned in ultrasonic cleaner. Cleaned specimens were kept in distilled water at $37{ }^{\circ} \mathrm{C}$ for $24 \mathrm{~h}$. All specimens were aged for 10.000 cycles, between 5 and $55^{\circ} \mathrm{C}$, dwell time $30 \mathrm{~s}$, transfer time $10 \mathrm{~s}$ (Thermocycler THE-1100, SD Mechatronik, Feldkirchen-Westerham, Germany). Then, each top surface of the samples roughened with a new diamond bur (150 $\mu \mathrm{m}$ grit size). Diamond burs was used with five back and forth strokes for a total of $10 \mathrm{~s}$ using a high-speed hand-piece under water-cooling. Samples were cleaned with water and air-dried. Subsequently, forty-four samples of each composite material were randomly assigned into four groups for surface treatments $(n=11)$.

Group 1: Phosphoric acid gel (35\%) + Porcelain primer + Clearfil S3 Bond Plus (positive control)

Group 2: Phosphoric acid gel $(35 \%)+$ single bond universal

Group 3: Phosphoric acid gel (35\%) + Clearfil Universal Bond

Group 4: Phosphoric acid gel (35\%) + Clearfil S3 Bond Plus

Materials used in the study are shown in Table 1 and the application steps are presented in Figure 1.

For the repair procedure, polyethylene tube (1.5 $\mathrm{mm}$ length, $0.8 \mathrm{~mm}$ internal diameter, (Unomedical, ConvaTec Limited, UK) was placed on the bonding area. Then, the same composite used in the preparation of discs, was packed into tube and cured for $20 \mathrm{~s}$. Thereafter, all samples were subjected to additional thermal cycling procedure as previously described. 


\begin{tabular}{|c|c|c|c|c|}
\hline Brand & Material type & Chemical composition & Application & Manufacturer \\
\hline $\begin{array}{l}\text { Single Bond } \\
\text { Universal }\end{array}$ & $\begin{array}{l}\text { Muti-mode } \\
\text { universal } \\
\text { adhesive }\end{array}$ & $\begin{array}{l}\text { MDP phosphate monomer, } \\
\text { Dimethacrylate resins, HEMA, } \\
\text { vitrebond }{ }^{\mathrm{TM}} \text { copolymer, filler, } \\
\text { ethanol, water, initiators, silane }\end{array}$ & $\begin{array}{l}\text { Applied the one coat adhesive with } \\
\text { disposable applicator to the entire } \\
\text { sample surface, rub it in for } 20 \mathrm{~s} \\
\text { and air dried the solvent with an } \\
\text { air syringe } 5 \mathrm{sec} \text {. Light cured } 10 \mathrm{~s}\end{array}$ & $\begin{array}{l}3 \text { M ESPE, St. Paul, } \\
\text { USA }\end{array}$ \\
\hline $\begin{array}{l}\text { Clearfil } \\
\text { Universal } \\
\text { Bond }\end{array}$ & $\begin{array}{l}\text { Muti-mode } \\
\text { universal } \\
\text { adhesive }\end{array}$ & $\begin{array}{l}10 \text { MDP, Bis-GMA, HEMA, } \\
\text { ethanol, hydrophilic aliphatic } \\
\text { dimethacrylate, colloidal silica, } \\
\text { camphorquinone, silane coupling } \\
\text { agent, accelerators, initiators, } \\
\text { water }\end{array}$ & $\begin{array}{l}\text { Applied the one coat adhesive with } \\
\text { disposable applicator to the entire } \\
\text { sample surface, rub it in for } 10 \mathrm{~s} \\
\text { and air dried the solvent with an } \\
\text { air syringe } 5 \mathrm{sec} \text {. Light cured } 10 \mathrm{~s}\end{array}$ & $\begin{array}{l}\text { Kuraray, Okayama, } \\
\text { Japan }\end{array}$ \\
\hline $\begin{array}{l}\text { Clearfil S3 } \\
\text { Bond Plus }\end{array}$ & $\begin{array}{l}\text { One-step self- } \\
\text { etch adhesive }\end{array}$ & $\begin{array}{l}\text { MDP, HEMA, Bis-GMA, hydrophilic } \\
\text { aliphatic dimethacrylate, } \\
\text { hydrophobic aliphatic } \\
\text { methacrylate, colloidal silica, } \\
\text { dL-camphorquinone, accelerators, } \\
\text { initiators, water }\end{array}$ & $\begin{array}{l}\text { Applied the one coat adhesive with } \\
\text { disposable applicator to the entire } \\
\text { sample surface, leaved in place for } \\
10 \mathrm{~s} \text {. Air dried the solvent with an } \\
\text { air syringe } 10 \mathrm{~s} \text {. Light cure for } 10 \mathrm{~s}\end{array}$ & $\begin{array}{l}\text { Kuraray, Okayama, } \\
\text { Japan }\end{array}$ \\
\hline $\begin{array}{l}\text { Porcelain } \\
\text { primer }\end{array}$ & & Silane with ethanol and acetone & $\begin{array}{l}\text { Applied the one coat porclain } \\
\text { primer with disposable applicator } \\
\text { to the entire sample surface, } \\
\text { allow to dwell for } 30 \text { seconds and } \\
\text { air dried the solvent with an air } \\
\text { syringe }\end{array}$ & $\begin{array}{l}\text { Bisco Inc., } \\
\text { Shaumburg, IL, USA }\end{array}$ \\
\hline $\begin{array}{l}\text { Clerarfil } \\
\text { majesty } \\
\text { esthetic }\end{array}$ & $\begin{array}{l}\text { Nano-hibrit } \\
\text { composite }\end{array}$ & $\begin{array}{l}\text { Bis-GMA, hydrophobic aromatic } \\
\text { dimethacrylate, hydrophobic } \\
\text { aliphatic methacrylate, } \\
\text { silanated barium glass filler, } \\
\text { pre-polymerized organic filler, } \\
\text { dL-camphorquinone, initiators, } \\
\text { accelerators, pigments }\end{array}$ & $\begin{array}{l}\text { Placed the A2 shade product into } \\
\text { the stainless steel mold as two } \\
\text { increments, and each intrement } \\
\text { cured for } 20 \mathrm{~s}\end{array}$ & $\begin{array}{l}\text { Kuraray, Okayama, } \\
\text { Japan }\end{array}$ \\
\hline K-etchant gel & & $\begin{array}{l}\text { Phosphoric acid, water, colloidal } \\
\text { silica, dye }\end{array}$ & $\begin{array}{l}\text { Applied it to the entire } \\
\text { sample surface for } 60 \mathrm{~s} \text {. Washed } \\
\text { thoroughly and dried with an air } \\
\text { syringe }\end{array}$ & $\begin{array}{l}\text { Kuraray, Okayama, } \\
\text { Japan }\end{array}$ \\
\hline
\end{tabular}

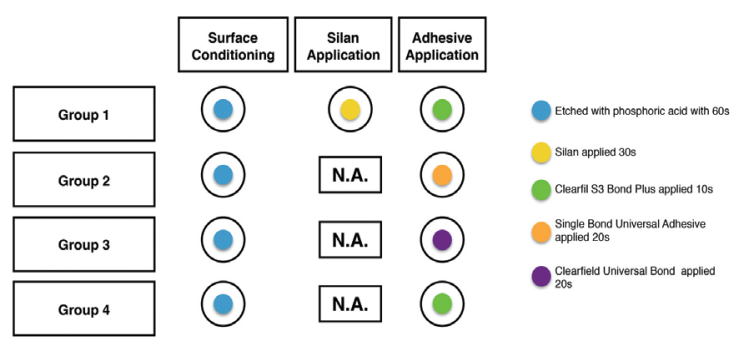

Figure 1. Application steps of repairing aged composite
The polyethylene tube was removed using a scalpel blade and each samples was surveyed with stereomicroscope to verify that no bonding defects, air bubble inclusions, or interfacial gaps were present.

\section{Micro-Shear Bond Strengths ( $\mu \mathrm{SBS}$ ) and Failure Analysis \\ Bond strength was tested with a universal testing machine (Z010, Zwick, Ulm, Germany). A shear force was applied to the adhesive interface through a chisel- shaped loading device at a crosshead speed of $1 \mathrm{~mm} /$ min. Load at debonding was recorded, and $\mu S B S \sigma$}


was calculated using the load at failure $F(N)$ and the adhesive area $A\left(\mathrm{~mm}^{2}\right)$ : $\sigma=F / A$.

The debonded area was inspected for failure mode analysis with a stereomicroscope at $25 \times$ magnification (M3Z, Leica Microsystems, Wetzlar, Germany).

The failure mode was classified as, cohesive in aged composite, adhesive at interface, cohesive in new composite (including failures within the adhesive layer and/or composite), mixed adhesive-cohesive.

One-way analysis of variance (ANOVA) and post hoc Tukey's multiple comparisons were used to determine statistical differences in $\mu$ SBS within groups at a significance level of 0.05 .

\section{Results}

The results of the $\mu$ SBS test are presented in Figure 2. Positive control group (Porcelain primer + Clearfil S3 Bond Plus) showed highest repair strength values and there is significant difference compared to the other groups $(p<0.05)$. Single Bond Universal and Clearfil Universal Bond groups showed similar bond strength values $(p>0.05)$. Clearfil S3 Bond Plus showed

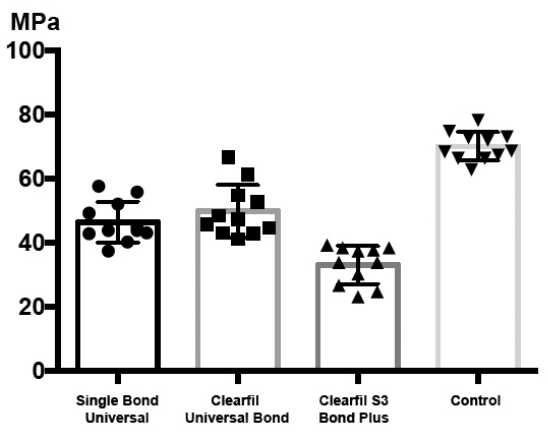

Figure 2. Micro-shear bond strength (MPa: Mega Pascal) of tested adhesives

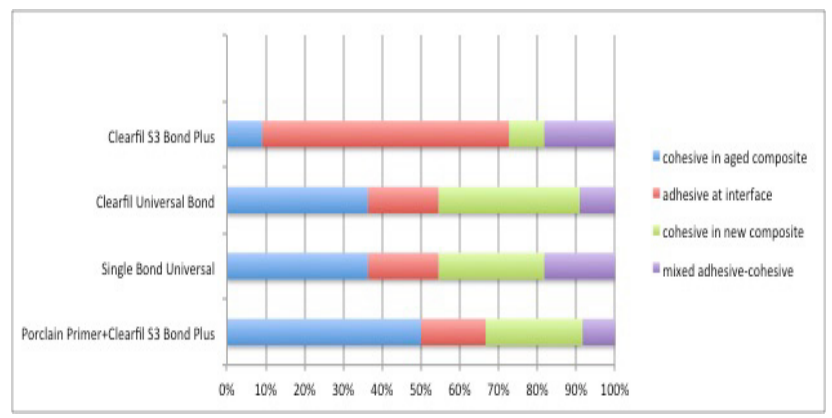

Figure 3. Failure mode (\%) for all groups of the composite specimens lowest repair strength values and there is significant difference compared to the other groups $(p<0.05)$.

\section{Failure Mode}

For positive control group most failures were "cohesive" in aged and new composite (81.8\%) and only a few fractures as "adhesive interface". On the contrary, in Clearfil S3 Bond Plus group most failures were adhesive interface (63.6\%). For universal adhesive groups (Single Bond Universal and Clearfil Universal Bond), similar to the positive control group, most failures were "cohesive" in aged and new composite (resp. $63.6 \%$ and $72.7 \%$ ) (Figure 3). No voids or porosities in the interface were detected.

\section{Discussion}

Repairing old composite restorations would be considered as a less invasive and cost-effective treatment approach to extend the service period of aged composite.

A great number of surface conditioning methods and adhesion promoters have been introduced to increase the repair strength of composites, such as roughening with burs, acid etching with hydrofluoric or phosphoric acid, air-borne particle abrasion with aluminium oxide with or without silane coupling agents and resin based adhesive systems (8,1518). Nevertheless, there is still no universal repair technique recommended for repairing the aged composite restorations (7).

Generally phosphoric or hydrofluoric acids are used as a conditioning agent for substrates. Phosphoric acid is effective on enamel and dentin but has no direct effect on surface characteristics of restorative materials (6). Moreover, studies have shown that phosphoric acid is not capable of increasing the micro-retentiveness of the surface $(19,20)$. However, some studies revealed that phosphoric acid treated specimens have higher repair bond strength compared to the negative control $(7,16)$.

Using hydrofluoric acid as a conditioning agent is another approach for repairing old composite restorations. Hydrofluoric acid dissolves glass particles in most of the composites resins but does not affect the resin matrix. Nevertheless, the effect of hydrofluoric acid is influenced by the composition of the filler particles in the composite material. For example, the effect of hydrofluoric acid on zirconium fillers is less than barium-glass fillers (6). Furthermore, 
several studies demonstrated that hydrofluoric acid have no effect in repairing composite restorations. (21-23). In addition, phosphoric acid etching is much safer than hydrofluoric acid for clinical use in patient mouth (24-26).

Following surface conditioning, chemical adhesion might be create using special primers (27). For this purpose, the most preferred material is a silane coupling agent which can function as mediators and promote adhesion between dissimilar, inorganic and organic, matrices through dual reactivity (28). Two types of Silanes are used in the dentistry; hydrolyzed and non-hydrolysed. The hydrolyzed silanes are readyto-use materials and they applied as a separate step in the bonding procedure. The nonhydrolized silanes must be activated with acid before use, therefore, depending on the adhesive system used, they are mixed with primer or adhesive (6). Researchers reported that the use of silane coupling agents significantly increased the bond strength of repaired composite resins $(18,27)$.

Repairing composite resins with phosphoric acid, followed by a silane application, probably combines best effectiveness with safety and seems to be the most feasible for dentists to use (7). Therefore, in this study the additional silan application was used as the positive control group for composite repair.

Recent trend in adhesive dentistry is to simplify bonding procedures by reducing the application steps (29). Universal adhesives contain many ingredients, such as bisphenol Aglycidyl methacrylate, hydroxyethyl methacrylate, 10-methacryloyloxydecyl dihydrogen phosphate, and/or silane. The manufacturer of universal adhesives claims that containing silane improved bonding to glass ceramics or resin composites without additional priming procedures.

According to the results of this study the repair strength is significantly higher when a separate step of silane is applied $(p<0.05)$. The application of silanecontaining universal adhesives alone was as not effective as the tested silane and adhesive combination $(p<0.05)$. However there is no significant difference between tested universal adhesives ( $p>0.05$ ).

Repairing old composite restoration is a minimally invasive approach that protects sound tooth structure and increases the longevity of restorations. However, chemical bonding between the repair composite and aged composite must be maximized to ensure an effective repair. According to the results of the study, in order to increase the restoration strength it is suggested to apply an additional silane step during the repair of composite restorations with universal adhesives. Further investigations with different composites, adhesive systems, and surface treatments should be conducted to improve this technique and provide awareness of this treatment option among dentists.

\section{Ethics}

Ethics Committee Approval: This study is a laboratory study. No human or animal origin tissue or organ was used in any part of the study. Therefore, it does not require ethical approval.

Informed Consent: This study is a laboratory study. No human or animal origin tissue or organ was used in any part of the study. Therefore, patient consent is not required.

Peer-review: Internally peer-reviewed.

\section{Authorship Contributions}

Surgical and Medical Practices: Null, Concept: G.D., Design: G.D., Data Collection or Processing: G.D., Analysis or Interpretation: G.D., G.G., Literature Search: G.D., G.G., Writing: G.D.

Conflict of Interest: No conflict of interest was declared by the authors.

Financial Disclosure: The authors declared that this study received no financial support.

\section{References}

1. Manhart J, Chen H, Hamm G, Hickel R. Review of the clinical survival of direct and indirect restorations in posterior teeth of the permanent dentition. Oper Dent 2004; 29: 481-508.

2. Gordan VV, Mondragon E, Shen C. Replacement of resin-based composite: evaluation of cavity design, cavity depth, and shade matching. Quintessence Int 2002; 33: 273-8.

3. Tyas MJ, Anusavice KJ, Frencken JE, Mount GJ. Minimal intervention dentistry--a review. FDI Commission Project 1-97. Int Dent J 2000; 50: 1-12.

4. Li J. Effects of surface properties on bond strength between layers of newly cured dental composites. J Oral Rehabil 1997; 24: 358-60.

5. da Costa $T R$, Serrano AM, Atman AP, Loguercio AD, Reis A. Durability of composite repair using different surface treatments. J Dent 2012; 40: 513-21.

6. Loomans B, Özcan M. Intraoral Repair of Direct and Indirect Restorations: Procedures and Guidelines. Oper Dent 2016; 41: S68-S78. 
7. Loomans BA, Cardoso MV, Roeters FJ, Opdam NJ, De Munck J, Huysmans MC, et al. Van Meerbeek, Is there one optimal repair technique for all composites? Dent Mater 2011; 27: 701-9.

8. Maneenut C, Sakoolnamarka R, Tyas MJ. The repair potential of resin composite materials. Dent Mater 2011; 27: e20-7.

9. Stawarczyk B, Krawczuk A, Ilie N. Tensile bond strength of resin composite repair in vitro using different surface preparation conditionings to an aged CAD/CAM resin nanoceramic. Clin Oral Investig 2015; 19: 299-308.

10. Muñoz MA, Luque-Martinez I, Malaquias $P$, Hass V, Reis $A$, Campanha $\mathrm{NH}$, et al. In vitro longevity of bonding properties of universal adhesives to dentin. Oper Dent 2015; 40: 282-92.

11. Cardoso MV, de Almeida Neves A, Mine A, Coutinho E, Van Landuyt K, De Munck J, et al. Current aspects on bonding effectiveness and stability in adhesive dentistry. Aust Dent J 2011; 56 Suppl 1: 31-44.

12. Üstün Ö, Büyükhatipoğlu IK, Seçilmiş A. Shear Bond Strength of Repair Systems to New CAD/CAM Restorative Materials. J Prosthodont 2018; 27: 748-54.

13. Al-Thagafi R, Al-Zordk W, Saker S. Influence of Surface Conditioning Protocols on Reparability of CAD/CAM Zirconiareinforced Lithium Silicate Ceramic. J Adhes Dent 2016; 18: 13541.

14. Elsaka SE. Repair bond strength of resin composite to a novel CAD/CAM hybrid ceramic using different repair systems. Dent Mater J 2015; 34: 161-7.

15. Rodrigues SA Jr, Ferracane JL, Della Bona A. Influence of surface treatments on the bond strength of repaired resin composite restorative materials. Dent Mater 2009; 25: 442-51.

16. Ozcan M, Barbosa SH, Melo RM, Galhano GA, Bottino MA. Effect of surface conditioning methods on the microtensile bond strength of resin composite to composite after aging conditions. Dent Mater 2007; 23: 1276-82.

17. Shahdad SA, Kennedy JG. Bond strength of repaired anterior composite resins: an it>/it> study1Previously presented at a research meeting of the Faculty of Medicine, Queen's University of Belfast.1. J Dent 1998; 26: 685-94.

18. Tezvergil A, Lassila LV, Vallittu PK. Composite-composite repair bond strength: effect of different adhesion primers. J Dent 2003; 31: 521-5.
19. Fawzy AS, El-Askary FS, Amer MA. Effect of surface treatments on the tensile bond strength of repaired water-aged anterior restorative micro-fine hybrid resin composite. J Dent 2008; 36: 969-76.

20. Hannig C, Laubach S, Hahn P, Attin T. Shear bond strength of repaired adhesive filling materials using different repair procedures. J Adhes Dent 2006; 8: 35-40.

21. Brosh T, Pilo R, Bichacho N, Blutstein R. Effect of combinations of surface treatments and bonding agents on the bond strength of repaired composites. J Prosthet Dent 1997; 77: 122-6.

22. Lucena-Martín C, González-López S, Navajas-Rodríguez de Mondelo JM. The effect of various surface treatments and bonding agents on the repaired strength of heat-treated composites. J Prosthet Dent 2001; 86: 481-8.

23. Rodrigues SA Jr, Ferracane JL, Della Bona A. Influence of surface treatments on the bond strength of repaired resin composite restorative materials. Dent Mater 2009; 25: 442-51.

24. Liu Y, Liu X, Xu X, Cen Y. Chemical injuries caused by hydrofluoric acid leak. Burns 2016; 42: 705-6.

25. Loomans BA, Mine A, Roeters FJ, Opdam NJ, De Munck J, Huysmans MC, et al. Van Meerbeek, Hydrofluoric acid on dentin should be avoided. Dent Mater 2010; 26: 643-9.

26. Szep S, Gerhardt T, Gockel HW, Ruppel M, Metzeltin D, Heidemann D. In vitro dentinal surface reaction of $9.5 \%$ buffered hydrofluoric acid in repair of ceramic restorations: a scanning electron microscopic investigation. J Prosthet Dent 2000; 83: 668-74.

27. Swift EJ Jr, Cloe BC, Boyer DB. Effect of a silane coupling agent on composite repair strengths, Am J Dent 1994; 7: 200-2.

28. Matinlinna JP, Lassila LV, Ozcan M, Yli-Urpo A, Vallittu PK. An introduction to silanes and their clinical applications in dentistry. Int J Prosthodont 2004; 17: 155-64.

29. Van Meerbeek B, De Munck J, Yoshida Y, Inoue S, Vargas M, Vijay $P$, et al. Buonocore memorial lecture. Adhesion to enamel and dentin: current status and future challenges. Oper Dent 2003; 28: 215-35. 